Goldschmidt 2021 Abstract

https://doi.org/10.7185/gold2021.3286

\section{Flux accounting and the retention ratio of antimony by cascade reservoirs in Guizhou Province, China}

\author{
QINGQING SUN ${ }^{1}$, KEQIANG PENG ${ }^{2}$ AND XIAOZHENG \\ $\mathrm{LI}^{3}$ \\ ${ }^{1}$ Tianjin University \\ ${ }^{2}$ State Key Laboratory of Ore Deposit Geochemistry, Institute of \\ Geochemistry, Chinese Academy of Sciences \\ ${ }^{3}$ School of Earth System Science, Tianjin University \\ Presenting Author: sunqingqing17@tju.edu.cn
}

In 2019, The reserves of antimony deposit are 380.6 kilotons in Guizhou, and the annual output was 13.95 kiloton, only will be mined for decades. The mining of arsenic, mercury, and gold ores in Guizhou have cumulative effects on the environment of antimony. Besides, Guizhou is a part of China's Power Transmission from the West to the East. There were 39.4 million tons of coal burned in coal-fired power plants. The abundant water resources are conducive to hydro-power in rivers in Guizhou. The retention ratio of cascade reservoirs on sediment transport rate was about $88 \%$. The adsorption of iron-manganese oxides and clay minerals in sediments fixed antimony and mineralization. Abundant organic matter of aquaculture imported led to the release fluxes at the sediment-water interface of step reservoirs in Wujiang River were $(2.18 \sim 12.28) \mathrm{nmol} \cdot \mathrm{cm}^{-2} \cdot \mathrm{yr}^{-1}$ monitored by thin-film gradient diffusion technique, indicating the risk of antimony release from sediment to water. The retention ratios of riverine antimony of step reservoirs in Duliujiang River were $1.61 \% \sim 66.51 \%$. The dams enhance the internal biogeochemical cycle and slow down the river transport of antimony. The highest concentration of antimony in the water flowing out of Dushan antimony ore was $2223 \mu \mathrm{g} / \mathrm{L}$, and that of sediment was $8955 \mathrm{mg} / \mathrm{kg}$ [1]. Arsenic fluoride endemic diseases caused by coal-burning have been controlled, health risks and hazards in antimony mining areas need to be valued. The in-situ microbial ecological remediation processors of the antimony mine can remove $95 \%$, reducing total antimony and antimony(III) in aerobic treatment stage and increasing $\mathrm{pH}$ and reducing Eh in the anaerobic one, with redox and biosorption of functional bacteria groups, e. g., Iron Oxidized Bacteria, Iron Reducing Bacteria, Sulfate Reducing Bacteria, Arsenic Oxidized Bacteria and Cyanobacteria [2]. It is necessary to develop materials substitute for antimony, enhance the secondary mining of waste ores, and recycle other antimony pools, cultivate superenriched plants (e. g., Pteris Nervosa, ramie), and Antimony Reducing Bacteria. Fluxes are showed in Figure2.

[1]Lu, et al., 2013, Journal of Guizhou University ( Natural Sciences),30(3):131-136.

[2] Enzong Xiao. 2017, University of Chinese Academy of Sciences. Ph.D. thesis.

[3] Chorover et al., 2007,Elements, 2007, 3(5): 321-326.

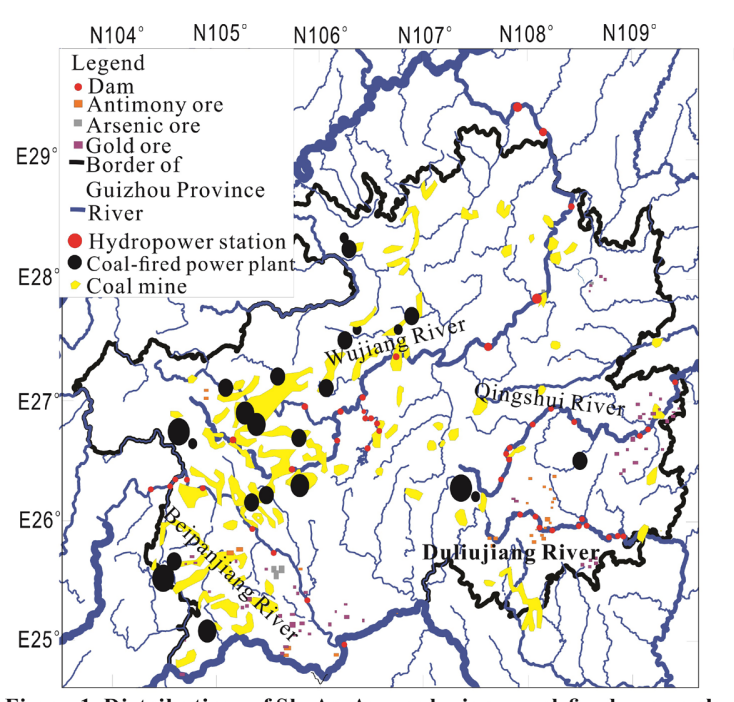

Figure 1. Distributions of Sb, As, Au, coal mines, coal-fired power plants and hydropower stations, Guizhou Province, China

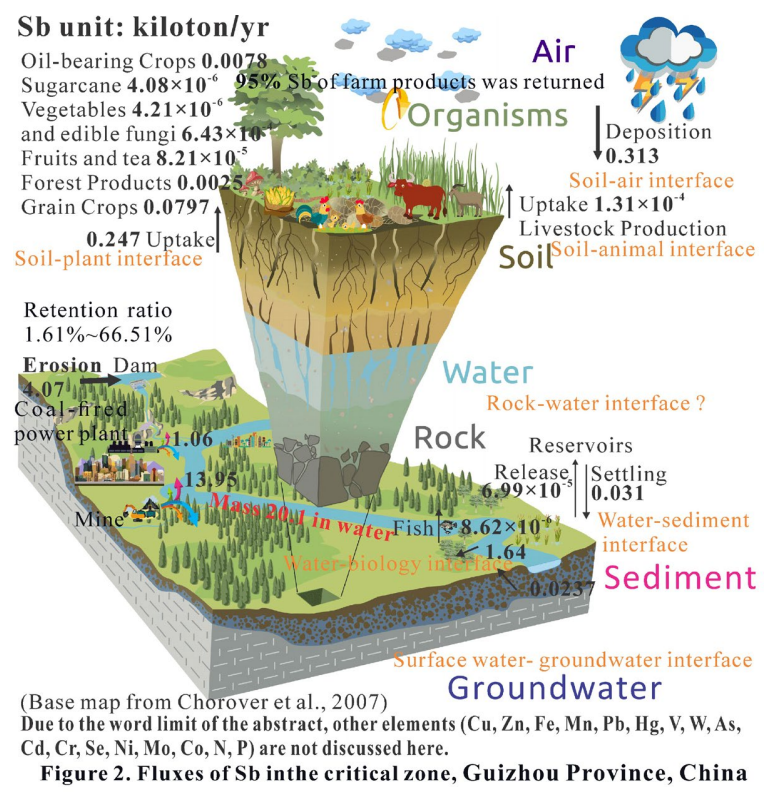

